\title{
THE CONCEPT OF MIXED GOVERNMENT IN CLASSICAL AND EARLY MODERN REPUBLICANISM
}

\begin{abstract}
This paper will present an analysis of the concept of mixed government in political philosophy, accentuating its role as the central connecting thread both between theories within classical and early modern republicanism and of the two eras within the republican tradition. The first part of the paper will offer a definition of mixed government, contrasting it with separation of powers and explaining its potential significance in contemporary political though. The second part will offer a comprehensive, broad analysis of the concept, based on political theories of four thinkers of paramount influence: Aristotle, Cicero, Machiavelli and Guicciardini. ${ }^{1}$ In the final part, the theories and eras of republican tradition will be compared based on the previous analysis, establishing their essential similarities and differences.
\end{abstract}

Key words: Mixed Government, Classical Republicanism, Florentine Realism, Early Modern Republicanism, Aristotle, Cicero, Machiavelli, Guicciardini.

\section{Introduction}

The roots of republican political thought can be traced to the antiquity and the theories of ancient Greek and Roman philosophers. As might be expected in the two and a half millennia that followed, our understanding of republicanism has been subject to frequent and, sometimes, substantial change. Yet, one defining element has always remained: the concept embedded in its very name, derived from the Latin phrase res publica (public good, or, more broadly, commonwealth), its implicit meaning being that the government of a state is meant to be accessible and accountable to all citizens, its goals being the goals not merely of certain classes and factions, but of society as a whole.

Today, republicanism is generally associated with the political systems of parliamentary democracies in the majority of European states, the United States of America and the members of the British Commonwealth. The philosophical

1 I use the terms classical and early modern republicanism to distinguish between the two eras within the tradition; it is worth noting that the concept of republicanism doesn't appear in theoretical discourse until the Enlightenment. Thus, referring to the theories of these authors as republican is essentially the same as talking about Plato's aesthetics, the term having been coined by 18-th century philosopher Alexander Baumgarten. 
foundation of this type of government can be traced back to the Enlightenment ideas that inspired the French Revolution, primarily those of Montesquieu (Montesquieu 1989, 156). In an attempt to combat absolutism, the system of monarchic government that was in place across the whole of Europe, with the exception of Great Britain, the Netherlands and the Polish-Lithuanian Commonwealth, and in order to counteract the possibility of its re-emergence, the concept of separation of powers was developed, comprehending that the legislative, the executive and the judicial are three specific, mutually independent branches of government.

The main purpose of this division was the prevention of executive overreach - its proper application would insure that the wielders of executive authority can neither craft laws to suit their interests, nor can they arbitrarily involve themselves in judicial procedures. States that have successfully applied the concept of separation of powers have distinguished themselves by political and economic stability, rule of law, individual freedom and minority rights. However, many of these states also face an increasingly obvious problem of unequal political representation stemming from economic inequality.

What is the cause of this inequality? Political theorist and prominent Machiavelli scholar John McCormick notes that, despite the formidability of the concept of separation of powers in combating absolutism and, more recently, totalitarianism, it is also characterized by a premise, that while rooted in the spirit of the Enlightenment and the ideas of human rights and natural equality, has no foundation in political reality: namely, the idea that a majority-elected government, owing its authority to the will of the people, will strive to represent the interests of all its citizens equally (McCormick 2011, 1).

McCormick claims that the majority of contemporary democratic theorists and policy analysts cannot answer a question that was central to pre-eighteenthcentury republicanism: "What institutions will prevent wealthy citizens from dominating a government that is supposed to serve the entire citizenry?" Seeing as this was a presupposed consequence in the ancient and early modern period unless suppressed institutionally, he bases his prescriptions for increasing the level of political equality in contemporary systems on the theories of early modern political thinkers from Renaissance Florence, the so-called Florentine Realists: Niccolo Machiavelli and Francesco Guicciardini. Despite the two millennia long historical "gap", these theories share many similarities with those of political philosophers from the epoch of classical republicanism, mainly Aristotle and Cicero, and greatly correspond to the political systems of both ancient city-states and Northern Italian late fifteenth and early sixteenth century republics.

\section{The Concept of Mixed Government}

The central moment that distinguishes classical and early modern republicanism from that in the Enlightenment and in our own era is the concept of mixed government. What does this concept comprehend and what makes it different from separation of powers? Quite similarly to our modern systems, it 
also entails a (frequently tripartite) separation of powers, the difference being that in this case, the separation is not based on governmental branching, but on economic strata and property assessments. The division that can, in one form, be argued to originate from Plato (Plato 2005, 239), is between monarchy, aristocracy and democracy as the "good" forms of government, with the "bad" ones, tyranny, oligarchy and anarchy being essentially their distortions. ${ }^{2}$

Monarchic government, despite the obvious implication, can, in practice, be simultaneously held by several people, usually from the wealthiest and most influential political families, with their positions often being hereditary. Furthermore, contrary to what the term may imply, these need not be kings or princes, but can also be the ancient and early modern equivalents of presidents, prime ministers and chancellors. Aristocratic government is commonly held by the nobility, usually within the so-called council of elders, or senate, the positions within which can be either hereditary or elective. The fulcrum of democratic government is the popular assembly or council of representatives, the members of which are elected from among the common people. The concept of mixed government comprehends that for a society to achieve the long-reaching goals of justice, freedom and stability, all three types of government must coexist in a system of checks and balances, the alternative being that a single mode, allowed to grow into its extreme, will inevitably deviate into its opposite.

Classical and early modern republican theorists founded this concept on the presupposition that, for lack of any of these forms of government, the social stratum that corresponds to it will necessarily fail to achieve political representation, which, in turn, will make the entire system unjust and unstable. For example, Sparta, which is historically remembered as a monarchy ruled by two kings, had a mixed government in Aristotle's view, with the council of elders and the council of representatives corresponding to the aristocratic and democratic element, respectively (Aristotle 1998, 52). Machiavelli held that Rome only became a republic after the establishment of the popular tribunes, following the ousting of Tarquinius Superbus, with all three forms of government having achieved representation: the consuls corresponded to the monarchic element, the senate - the aristocratic, and the tribunes - the democratic element (Machiavelli 1996, 14).

In addition to the need for all social strata to achieve representation through their respective forms of government in order for a society to be stable, the concept of mixed government simultaneously supervenes on the implicit virtues of the different forms of government while protecting from their respective vices. The virtue of monarchy is held to be in the paramount political knowledge, skill and virtue of the one or the few in authority; that of aristocracy, in the competence and experience of the ruling minority, required to handle the

2 The terms used to describe these forms vary greatly from one theorist to another: in Aristotle's terminology, for example, kingship corresponds to monarchy, and polity to wellordered democracy; Machiavelli names monarchy principality, aristocracy government of the great and democracy government of the people. However, in spite of the terminological distinctions, these names retain the same essential meaning throughout all theories. 
complexities of challenging political issues, and the virtue of democracy is held to be in the freedom and equality for of the majority and in the legitimacy that stems from its consent.

As all of these forms of government are susceptible to corruption and deviation, their mixture is also meant to prevent their regression into their distortions, the primary distinction being that the "good" forms of government strive for the well-being of the entire society, while the corresponding "bad" forms serve the narrow interests of the individuals or groups in power (Aristotle 1998, 78). Thus, the only purpose of tyranny is the boundless accumulation of power and wealth by the tyrant; that of oligarchy is the exclusion of the poor from the government for the unimpeded realization of the interests of the rich, while that of anarchy is the full redistribution of wealth for the benefit of the poor and to the detriment of all others.

Good constitutions and forms of government are, therefore, also distinguished from bad ones by their laws, which, besides being clear and comprehensive, also need to be consistently followed, establishing the groundwork for a free, stable and just society. Actually creating such a society is an age-old problem to which the concept of mixed government should be regarded as a republican solution founded on realist principles: by building upon the lawful basis of a good constitution, it seeks to appropriate and combine virtues inherent in the three good forms of government, while counteracting the vices of their deviations, constantly ensuring that all social strata are represented, with partaking in the government being seen as the only meaningful way of realizing their political interests.

\section{Aristotle, Cicero, Machiavelli, Guicciardini}

As we present a basic overview and analysis of the theories of these four great thinkers, we'll primarily focus on each one's particular understanding of mixed government. The first step in this analysis will be to describe the social and political circumstances they wrote in, as well as the particular intention with which they approached their works. The second will be to explore their worldview in the descriptive sense, as the foundations upon which their political prescriptions are based. The third will be to focus on the substance of their theories, analyzing their views on how government should be constituted, what its role and limits are and how these differ across various circumstances, if there is an ideal form of government and, for our inability to create it, what its best alternatives are.

Aristotle was born a free man to a well-off family in Stagira, northern Greece. At a young age, he was sent to Plato's academy where he went on to become a teacher and researcher. He would eventually become the tutor and mentor of the famous conqueror, Alexander the Great (Reeve 1998, xvii). As a man who enjoyed considerable privilege, Aristotle challenged few social and cultural dogmas of his day, his position towards slaves and women perhaps being the most notorious one he held (Aristotle 1998, 8). He was nevertheless a man of immense practical 
wisdom who approached political theory from an entirely different angle from his teacher, Plato, whose system he criticizes before presenting his own. Rather than going into great detail about the ideal society and state, his main work on the subject, Politics, is filled with practical prescriptions for reforming existing constitutions, based on comparative historical analysis and greatly benefitting from his remarkable knowledge of history.

In the ancient world, Greece was not a unified state that we know today, but rather a large collection of independent city-states that stretched from the western coast of Asia Minor to Southern Italy and Sicily, with vast social differences and political rivalries that quite often resulted in large scale wars. These city-states were, nonetheless, connected by a long thread of common culture, religion and customs, and while there were as many forms of government as there were city-states, ranging from monarchies, across oligarchies, to democracies and vast numbers of mixed regimes in between, all of them were populated by a minority of free citizens with political rights generally dependent upon property assessments, while the women, slaves and foreigners had no institutionally recognized power whatsoever.

Rather uniquely, and in great contrast to the social contract theories of the Enlightenment, Aristotle saw the state as a natural phenomenon (Reeve 1998, xlviii), and humans as animals with a natural tendency toward forming society, with anyone that didn't need it by virtue of being self-sufficient being seen as "either a beast or a god" (Aristotle 1998, 5). Aristotle's brand of realism is centered around the acceptance of certain political facts to the exclusion of attempting their change: for example, that enslavement is no less legitimate than hunting or any other form of property acquisition (Ibid., 14), that "vulgar craftsmen and hired laborers" can never be truly equal to free men (Ibid., 74), and that virtue naturally escapes the common man, which is why the majority can attain it only through military service (Ibid., 77).

His division between good and bad forms of government is based on two primary criteria: their lawfulness, or lack thereof and the state's apparent (as opposed to stated) goals. The good constitutions, whether in the hands of kings (kingships), the rich (aristocracies), or the poor (polities), are characterized by just laws and a clear governmental focus on benefitting the entire society rather than the narrow interests of the ruling social strata (Ibid.). By contrast, their deviations are typically either lawless, or their laws are routinely ignored and the ruler(s), whether an individual (tyranny), a rich minority (oligarchy) or a poor majority (democracy) holds power, seek nothing but their own benefit to the constant detriment of society as a whole (Ibid., 78).

As the foundational elements in his political theory, Aristotle defines the city-state as a community of households and families whose end is a complete and self-sufficient life (Ibid., 81) and civic virtue as the capacity to rule and be ruled in turn (Ibid., 72). Briefly identifying a true, natural aristocracy as the ideal form of government (Reeve 1998, lxxii), with all of the extant aristocracies and other regimes being its deviations, Aristotle immediately recognizes the fact that most city-states are generally either oligarchies, democracies or a mixture between the two. 
Elaborating upon his view of the three basic good and bad forms of government, Aristotle acknowledges that they have several different varieties each, based on the different methods of acquisition and transfer of power, property assessments, wages and taxes for assemblies, as well as other factors. In this context, and in regards to his briefly mentioned ideal constitution of natural aristocracy, he goes on to point out that "one should not study only what is best, but also what is possible" (Aristotle 1998, 102) and identifies tyranny as the worst form of government, being the furthest removed from a well-ordered constitution, oligarchy as the second worst, and democracy as the most moderate.

Aristotle opposes the general definition of oligarchy as the rule of the few and democracy as that of the many, as there have been examples, albeit a few, of city-states where the ruling majority was rich and the subject minority poor; he proposes a more narrow definition, which asserts that democracy is the rule of the free and oligarchy that of the rich (Ibid., 106). The need for mixed constitutions, therefore, naturally arises from the fact that most existing constitutions are of the bad forms, by and large being either oligarchic or democratic. Their potential remedies also represent something inherently more virtuous, the two opposing good forms being defined as such not only on the basis of their lawfulness and commitment to the common good, but also on mixed government, with polity being a mixture of oligarchy and democracy that leans toward the latter, while aristocracy tends to lean toward the former (Ibid., 115).

Seeing as the institutional enactment of this mixture presents a peculiar problem, Aristotle proposes a solution that is based on combining the different policies of oligarchies and democracies, all of which are purposed toward facilitating the level of the ruling strata's participation in government. Thus, oligarchies fine the rich for failing to appear in court cases, while democracies pay the poor to appear; oligarchies require a large property assessment for membership in the assembly, while democracies require none; the former conduct the election of public officials by vote, the latter by lot (Ibid.). Mixed constitutions, whether referring to aristocracies, polities, or something in between, should, therefore combine all of these elements, thereby creating a middle ground between existing legislative practices, that results in a greater balance of political power, preventing any social strata's representation from attaining too much power and transforming the constitution into its opposite, deviant form.

Furthermore, Aristotle places great emphasis on moderation and equality: a city-state in which the middle class is the most numerous will tend to have the greatest longevity, seeing as they neither desire the property of others, nor is their property desired (Ibid., 120). He insists that the political community dominated by those in the middle will be the best and the most well governed; that the middle class should, therefore be stronger than both the rich and the poor or, failing that, at least one of them. Both extreme democracy and unmixed oligarchy tend to give rise to factionalism, which often results in tyranny, whether in case of the rich minority choosing a guardian to suppress the masses in their name, or in case of the poor majority electing a champion to combat the will of the 
oligarchs (Ibid.). In either case, the ensuing factional tension merely represents the stepping stone for a would-be tyrant to rise to power by presenting himself as the defender of the disadvantaged.

Further illustrating the danger of unmixed constitutions, Aristotle notes that the reason why most city-states tend to give rise to either oligarchies or democracies is because those in the middle tend to be fewer and weaker than the rich and the poor, with either of the latter two taking superiority resulting from their dissentions as reward for their victory, and proceeding to establish neither a common constitution, nor an equal one (Ibid., 121). Therefore, he sees a state with just laws and a mixed government founded upon the middle class as the most stable and lasting system that preserves both freedom and wealth, while guaranteeing political rights through representation to all social strata.

Cicero was a Roman statesman and philosopher who lived during the turbulent era of the republic's impending downfall. Born to an equestrian family, he was a proud member of Rome's ancient aristocracy who had attained his political influence through both virtue and noble blood. Having exposed a conspiracy to overthrow the Roman republic as a consul, he was regarded as an outstanding statesman whose support was sought by many politicians, while having experienced first-hand the many machinations of various factions, including both the first and the second triumvirate. He was also personally hurt by them: his opposition to Caesar (Featherstonhaugh 1829, 8) meant that he was forced to spend some of his life in exile. A notable patriot and staunch defender of republicanism, he saw the rapid shift toward imperialism as a paramount threat to Rome's political institutions and society and sought to halt the influence of ambitious individuals and divisive factions by returning to the roots of what had once made his country into a free and stable republic (Ibid., 2).

A knowledgeable scholar of Greek philosophy, Cicero introduced the concepts of most major Greek schools of philosophy into Roman thought. His particular admiration for Plato, whom he praises on several occasions (Cicero $1829,42)$, is evident in the way he writes, his main political treatise, On the Commonwealth, having been written as a platonic dialogue, with the famous Roman statesman and general Scipio Africanus taking the role that would normally belong to Socrates. Despite the considerable similarity of style, the substance of Cicero's work, a historically based analysis of republicanism founded upon realist assumptions about man and society, bears far closer resemblance to the works of Aristotle; indeed, their political theories hold enough similarities to rightly be considered a part of the same school of political though that would act as the foundation of the republican tradition.

Primarily basing his analysis on a detailed knowledge of Roman history, Cicero's goal in his treatise is twofold: on the one hand, much like his Greek predecessors, he offers a theoretical framework of government, which, in his case, much like in Aristotle's, is meant to be highly applicable to republics; on the 
other hand, his primary goal is to find the salvation from Rome's current decline, which he sees in returning to the republic's early constitution, it being a wellbalanced system of institutions, ensuring the realization of each social stratum's political interests.

Cicero opens his discourse by describing a strange natural phenomenon of two visible suns, which could have been meant as a metaphor for the disunity between the senate and the people, resulting from factional strife, and signaling the republic's impending collapse (Cicero 1829, 53). He goes on to offer what could be the earliest historical definition of a republic, outlining that "A republic or commonwealth then, is the wealth or common interest of the people" (Ibid., 56). To insure its permanence, it must be governed by that authority which has a strong relation to the causes by which the republic came into being, namely, "the three modes of government" (Ibid., 57).

These modes aren't the specialized Enlightenment era branches of government, but rather public offices corresponding to the three different social strata. Acknowledging the traditional division between the three basic forms of government and their respective deviations, Cicero immediately points out their many shortcomings, while accepting that democracy is still the best among them for its common, equal enjoyment of freedom (Ibid., 60). In his view, subjects within kingdoms are too much deprived of common rights; under an aristocratic government, the people are not admitted into public office and therefore, cannot realize their interests, and under the majority, equality itself becomes unjust, as it admits no allowance for degrees of rank based on nobility and virtue (Ibid., 58).

Cicero claims that all extremes of a seemingly agreeable nature are inevitably converted to their opposites: the destruction of an aristocratic government proceeds from its unlimited power; the people's slavery arises from their boundless freedom just as tyranny springs from the most licentious liberty (Ibid., 75). These observations can be linked to Aristotle's belief that both unmixed oligarchy and extreme democracy tend to give rise to tyranny. Their stances differ in this regard though, as Aristotle believes a natural aristocracy to be the ideal constitution, while Cicero prefers the monarchy for its stability, as well as the danger of oligarchy and democracy lapsing into tyranny (Ibid., 77). He further promises an outline of the ideal constitution, much like the one in Plato's republic (Ibid., 80), but, as is the case with some others, the portion of the book in which he discusses it was, sadly, lost to history (Featherstonhaugh 1829).

Recognizing the monarchy as the most stable mode of government, democracy as the freest, and aristocracy as having the highest degree of political skill and virtue among its leadership, Cicero is nonetheless dissatisfied with their shortcomings, even in their good, uncorrupted forms: "Therefore I think a fourth kind of government, moderated and mixed from those three of which I first spoke, is most to be approved" (Cicero 1829, 60). He further says: "separately I do not approve of any of them; but should prefer to every one of them, a government constituted out of all three" (Ibid., 65). In pointing out that the state was never sound when the senate governed alone and that under kingdoms, the disadvantages were worse yet (Ibid., 61), he is likely referring to the early history 
of the Roman republic - the ousting of the last king, Tarquinius Superbus and the ensuing domination of the nobility in which the senate, alongside the consuls, enjoyed a monopoly on political power, though this could also be ascribed to kingdoms and aristocracies in general.

The implicit crucial moment of change here, which we'll see explored in greater detail in Machiavelli's theory, is the introduction of the institution of popular tribunes: upon its creation, all social strata had gained political representation through their respective modes of government, with the consuls representing to the monarchical mode of government, the senate corresponding to the aristocratic, and the tribunes to the democratic form (Cicero 1829, 107). However, as the enactment of the tribunes did little to curb the power of the senate in practice, a further push for democratic reform was made, by relinquishing political power to a new body, the decemvirate, tasked with reforming Roman laws after those of Athens. Their leader, Apius Claudius, who had previously shown tyrannical tendencies, reverted to his old ways, causing his government to fall to a revolution supported by both the people and the nobility (Ibid., 109), with the republic's mixed constitution being restored and functioning in relative harmony for several following centuries.

Cicero holds that the strength of laws rests in punishment and not in our natural justice and, furthermore, that natural right does not exist (Ibid., 121). He places special emphasis on the dangers of extreme democracy, likening Claudius' tyranny to those of Dionysius in Syracuse and Pisistratus in Athens (Ibid., 128). Finally, Cicero laments about the posterity and suggests that the republic's immortality might have been possible had the institutions of the Roman forefathers been preserved (Ibid., 126).

Renaissance Florence - home to both Niccolo Machiavelli and Francesco Guicciardini - was the vanguard of cultural and social transformation, while being embroiled in a centuries old internal struggle between the various factions holding power in Italy. Like ancient Greece, late fifteenth and early sixteenth century Italy was not the unified country that we know today, but rather a tumultuous mixture of small domestic maritime republics, interspersed with lands controlled by great foreign powers and the Vatican. The discord arising from their frequent wars meant that they could never contend with the large countries of Western Europe in terms of political and military power; nonetheless, they were at the forefront of technological and cultural development, never more so than during the Renaissance.

While the earliest roots of the cultural and social rebirth can be traced to the rediscovery of the works of Aristotle in the twelfth century, the fifteenth century can undisputedly be seen as its true beginning, with a drastic decrease of the church's influence (Mansfield and Tarcov 1996, xvii). The Renaissance can best be described as a revival of classicism and humanism, which had until then been repressed by the church: in addition to the reinvigoration of antiquity-inspired arts and sciences, philosophy, political though in particular, gained much 
traction, especially among the Italian states that much resembled the ancient city-states of Greece.

On the eve of the sixteenth century, the period of substantial cultural change also took a radical social turn in Florence: having been a relatively stable oligarchic republic for several centuries, its political structure was deeply shaken by the government of Gonfalonier (chief executive) Piero Soderini, whose reforms, centered on the creation of the Great Council, led to him being labelled a class traitor by most of the nobility (McCormick 2011, 40). This is the primary source of difference in the perspectives of Machiavelli and Guicciardini, with the former having been a member of the emergent class of professional bureaucracy within the new democratic government, while the latter served as an ambassador based on his lineage, a noble family of paramount influence that had produced no less than sixteen gonfaloniers in the past (Moulakis 1998, 27).

Having achieved his position in the Soderini government based on merit, Machiavelli still felt the brute end of the nobility's nepotism when they stifled his appointment as ambassador to the Holy Roman Empire. As the republic's wealthiest families held great influence in spite of the democratic reforms, the Gonfalonier was forced to submit to their demands (McCormick 2011, 40). This turn of events in addition to Machiavelli's ousting from political life after the fall of the Soderini government left the famous political thinker embittered toward the great, both for their misdeeds against the republic and against him.

The magnum opus of Machiavelli's political theory, The Discourses on Livy, even to this day remains in the shadow of the much shorter and more poignant work, The Prince. Harshly judged for immorality and rejection of religion by contemporaries (Kahn 2010, 240) and later interpreters (Strauss 1957, 36) alike, this brisk guide for a would-be ruler has no theoretical aspirations beyond basing an impromptu government on borderline extreme assumptions regarding man and society, the grim measures being undertaken to ensure the success of a goal directly linked to the turbulent period in which Machiavelli wrote: the unification of Italy and its liberation from "the barbarians", the many foreign powers that ruled a number of its regions (Machiavelli 1998, 101). And while the republican beliefs that he would greatly elaborate upon in his main theoretical work do surface in The Prince occasionally, the most significant being that "the end of the people is more decent than that of the great, since the great want to oppress and the people want not to be oppressed" (Ibid., 39), they are frequently overshadowed by the permeating advocacy of ruthlessness.

With quotes such as "it is much safer to be feared than loved" (Ibid., 66), "it is necessary to a prince, if he wants to maintain himself, to learn to be able not to be good, and to use this and not use it according to necessity" (Ibid., 61) and "men should either be caressed or eliminated, because they avenge themselves for slight offenses but cannot do so for grave ones" (Ibid., 10), we simply cannot be puzzled by the infamy that Machiavelli had garnered, though it should be noted that Guicciardini, while choosing his words more carefully, paints a no less grim picture of political reality. 
Machiavelli has been described by some as a complex and deliberately enigmatic writer, much of which has to do with the period in which he wrote (Pocock 2010, 144). The obscurity of his true intentions in The Prince notwithstanding, the substance of his theory greatly transcends the pages of that book, as it barely scratches the surface of the concepts he would come to explore in much greater detail in his magnum opus, The Discourses on Livy: a vast, allencompassing work of political philosophy, rooted in deep historical analysis, The Discourses forsake the particular, time-bound goals of contemporary politics in favor of establishing a system founded upon timeless laws of state and society.

With tremendous apparent influence from the works of Aristotle and Cicero, Machiavelli seeks to establish a system of institutions conforming to the unseen laws of political reality, while using republics both contemporary and ancient as a fount of practical examples. His main inspiration is the Roman republic, whose political reforms and institutional practices he takes as the paramount example of republicanism firmly based in and corresponding to realist assumptions about the nature of politics.

The main part of his discourse is centered on the institutional developments that followed the ousting of Rome's last king, Tarquinius Superbus, which would come to shape the politics of the republic for several following centuries. He begins by comparing the various ways in which republics can be created, concluding that Rome's foundation by Romulus established its independence from the beginning (Machiavelli 1996, 9), while the freedom of its citizens was enhanced by a flexible lawmaking process, which, unlike that of Sparta, meant that laws were enacted and evolved over a long period of time in order to adapt to the changing political circumstances (Ibid., 10).

Accepting the traditional tripartite division of government, Machiavelli immediately points out that principality easily becomes tyrannical, aristocracy regresses into government of the few and the popular government inevitably turns licentious, because of the likeness that virtue and vice have in their cases (Ibid., 11). With the three good modes having been shown to be short-lived, and their deviations malign, Machiavelli arrives at the conclusion quite similar to those of Aristotle and Cicero: that "those who prudently order laws having recognized this defect, avoiding each of these modes by itself, chose one that shared in all, judging it firmer and more stable: for the one guards the other, since in one and the same city there are the principality, the aristocrats, and the popular government" (Ibid., 13). Thus, he praises Lycurgus of Sparta for establishing a mixed government through a clear and just system of laws that ensured the state's longevity, while criticizing Solon of Athens for establishing a popular government that regressed into tyranny within his lifetime.

Recognizing Rome's initial kingship as one of the state's many defects that had to be fixed over time, he contrasts republics that were stable and wellordered from the beginning with the ones that were forced to evolve through the circumstances arising from their imperfection. As mentioned previously, Rome had not yet become a true republic, as classical and early modern theorists understood the concept, immediately upon the ousting of the last king: with 
political power being shared between society's elites that expressed their will through the consuls and the senate, the people had no voice of their own within the government, which is what leads Machiavelli to the conclusion that the creation of the popular tribunes made the republic more perfect (Machiavelli 1996, 15). What makes his analysis of exactly how this transpired particularly original and provocative is the claim that the enactment of the office of tribunes resulted not from peaceful cooperation, but from disunion and collision between the senate and the people: "I say that to me it appears that those who damn the tumults between the nobles and the plebs blame those thing that were the first cause of keeping Rome free, and that they consider the noises and the cries that would arise in such tumults more than the good effects that they engendered" (Ibid., 16). This is fully within the spirit of his consequentialist approach, perhaps best formulated by his maxim: "when the deed accuses him, the effect excuses him" (Ibid., 29).

Finally, Machiavelli places great emphasis on well-ordered legal institutions, insisting that the Roman practice of public accusations was instrumental to both checking the power of the nobility, as well as keeping order in society. Using the example of Coriolanus, an enemy of the popular faction who attempted to starve the people into submission, he claims that, had the tribunes not levelled a public accusation against him, he would have been killed in a riot. The functioning of such legal institutions insures that justice is served even if the accuser is acquitted, inspiring fear in those who conspire against the common good, while allowing the people to vent their anger against the nobility (Ibid., 24). In addition to good laws, practices like this one are meant to ensure the republic's stability even in the most tumultuous of times.

The personal and political experience of Machiavelli's contemporary and fellow citizen, Francesco Guicciardini, whom he admired greatly, in spite of their disagreements (Moulakis 1998, 35), had been very different. Born to a noble family of paramount influence, he was groomed for high office from his youth; having received a doctorate in law, he joined the opposition against Gonfalonier Piero Soderini (Ibid., 28). In order to pacify the nobles, who retained much of their traditional privileges despite his democratic reforms, Soderini appointed Guicciardini as ambassador to King Ferdinand of Aragon. Whilst abroad, Guicciardini bore witness to the steady deterioration of Florence, which eventually prompted him to write a discourse on bringing order to popular government, naming it Discorso di Logrogno, after the town in Northern Spain where it was written.

In one of the great ironies of history, he finished the Discourse merely several days after the Soderini government fell to the Medici restoration (Ibid., 30). While being strongly critical of the ideas of Friar Savonarola, whose teachings inspired Piero Soderini, he admired the essence of his democratic reforms, particularly the creation of the Great Council, for the constitutional balance it provided (Ibid., 83). In accordance with their different social station, 
Machiavelli and Guicciardini took opposite views of political power in society: while the former took a chancery view of the emerging modern state, focusing on professional civil servants, the latter saw social continuity and coherence as dependent upon the political class whose members were distinguished by their knowledge and experience in the affairs of state (Ibid., 80).

Taking a generally elitist approach to government, Guicciardini insists on the importance of qualified majorities for the election of most officials and in the Senate's decision-making process (Ibid., 102). He prohibits debates within the Great Council, making them exclusive to the Senate from which legislation originates, while perceiving the office of the Gonfalonier as a guarantee of stability, unity and effectiveness of executive action (Ibid., 109). This system does not, however, prevent the people from taking an active role in politics, but rather relegates that role to legitimating and ratifying decisions made by the Senate and the Gonfalonier, based on Guicciardini's belief that the many lack the capacity and expertise required to deal with the complexities of government, but can be trusted to defend liberty, check tyrannical aspirations and advance the general welfare (Ibid., 105).

Establishing that "Political rule and command are nothing but violence over subjects, occasionally mitigated by a pretense of decency" (Guicciardini 1998, 121) and further, that "Liberty is nothing but the supremacy of law and public decrees prevailing over the desires of individuals" (Ibid., 122), Guicciardini founds his reforms upon firmly realist principles, while centering them on the aristocracy and its corresponding office, the Senate. Rather originally, he actually rejects the tripartite division of government, considering it to be open to abuse by demagogues, while claiming that Florence is too accustomed to liberty to have any need for its generality (Moulakis 1998, 99); nonetheless, his division of government is apparently based on the traditional system, as clearly evidenced by both the presence of all three modes in the offices of the Gonfalonier, the Senate and the Great Council, and in their respective roles, embedded in their connection with the social strata they represent.

Being the highest office in the republic, the primary virtue of the Gonfalonier, elected for life from among the most influential noble families, is political skill and experience (Guicciardini 1998, 124); however, with the power that enables the embodiment of that virtue also comes the risk of the people falling under the chief executive's influence, which may give rise to tyranny: "Experience shows and reason confirms that as a result of its weakness the multitude is never ruled by itself, but always seeks an allegiance and a prop" (Ibid., 125). Therefore, "To maintain true and complete liberty one of the most important things is surely this: that there be a mean by which the ignorance of the multitude can be controlled and the ambition of the Gonfalonier kept in check" (Ibid.).

The delicate position of the Gonfalonier must be carefully managed, as excesses could make him either useless, or a tyrant. In the process of his selection, three candidates should be proposed by the Senate, with the final election being left to the Great Council (Guicciardini 1998, 135). In its primary capacity as the barrier against the nobility's political monopoly, the Great Council has the 
final say in most essential laws and decrees, being barred only from decisions that require secrecy, as is the case with espionage and warfare. In this regard, it's important to note that while Guicciardini shares Machiavelli's grim view on human nature, he perceives the many, and not the few, as the embodiment of the worst in humanity, seeing the Great Council as rampant with ambition, evil and ignorance (Ibid., 126).

Nevertheless, being the body that represents the largest majority of the republic's citizens, its cooperation is the condicio sine qua non of any political undertaking: its contestatory role is based around the power to bar the decisions of any other office, including those of the Senate and the Gonfalonier, as well as those of smaller, elite bodies like the Council of Eighty, the Ten of War and the Signoria. In this regard, the originality of Guicciardini's system lies in withholding participatory powers from the Great Council, limiting its role to legitimation and ratification (Ibid., 128). While no decision, regardless of its perceived wisdom among society's elites, can justifiably be considered legitimate without the consent of the majority that it affects, Guicciardini argues that their deeper involvement in the process of decision-making would cause confusion, when taking into account the Great Council's vast membership, as well as the members' limited political competence (Ibid., 139).

The main body of deliberation and lawmaking is, therefore, the Senate: it represents balance and brings together the extremes of the one (Gonfalonier) and the many (Great Council), safeguarding liberty through laws (Ibid., 136). Its membership should consist of all the republic's wise men, chosen both for their noble lineage and their virtue, as "in fact, the entire weight of government ultimately rests on the shoulders of very few" (Ibid., 137). In defining the functioning of the Senate and its relation to the Gonfalonier and the aforementioned elite bodies of government, emphasis must be placed on wellinformed deliberation, ensuring that members of the Senate are both presented with detailed proposals and given enough time to debate about them.

To further facilitate discussion, participants should be allowed to present multiple opinions, even if these run contrary to the organs they are part of, with even the Gonfalonier himself being allowed no more power than the senators during the process (Guicciardini 1998, 141). Here, Guicciardini contrasts his well-ordered system with the somewhat arbitrary rule of Piero Soderini, who, despite having made considerable progress toward a republican government by establishing the Great Council, still demonstrated dangerous ambition by pitting different factions against each other and manipulating votes (Ibid., 140).

\section{Mixed Government: Tracing the History of an Idea}

The republican tradition of western political thought is notoriously difficult to frame: while the term "republicanism" only entered broad theoretical discourse during the Enlightenment, its central concepts could be argued to have reached their zenith a few centuries before that, while separated from their original intellectual foundations by no less than two millennia. Though the idea 
of separation of powers became the defining characteristic of republicanism under the sweeping influence of Montesquieu's theory, its substantial difference from mixed government cannot simply be dismissed as the product of a lack of theoretical sophistication in the earlier period, as the political reality of our era has exposed the defects of the branching of government based upon the modes' role, and not the strata they stand to represent.

By contrasting the concepts of separation of powers and mixed government, we identified this distinction as the primary source of their difference. Furthermore, in following the history of the latter idea, we accentuated its central role in the theories of the four great thinkers, which displayed substantial similarity, in spite of their different personal and political circumstances and of the long gap between the two eras. On the one hand, the similarities can be somewhat comprehended when considering that the Renaissance was marked by the reinvigoration of interest in the classical period and its cultural and intellectual products. On the other, the subtle, but notable differences between the two eras point to the idea's survival through tenuous transformation, raising an intriguing philosophical question: did the early modern republican theorists simply excavate the long-forgotten concepts of the classical thinkers, or might have they, perhaps, arrived at similar conclusions through a different approach?

To answer this delicate question, we might have to look beyond their conclusions, and into the foundations of their discourses. The overview of each of the four theories has demonstrated the undisputed, central role of mixed government, stemming from the brevity of the good modes of government and the malice of the bad ones, as each author strongly criticized all three forms, and emphasized their defects in either theory or practice. Their insistence on the importance of laws as the guarantee of a lasting system is also directly linked to the concept of mixed government, as unchecked power of any social stratum is seen as one of the most pernicious threats to legality, and the greatest source of arbitrary rule. While making a just system based on any of the three modes of government is acknowledged to be theoretically possible, the difficulty of realizing it in practice mainly stems from the fact that any stratum, having been given too much power, will inevitably seek to use the state to its own benefit, even if it means abridging laws and causing detriment to others.

Closely linked to the issue of clear, just laws is the matter of institutions that embody them, their functioning being among the few substantial guarantees of preventing arbitrary rule; this applies both to legal institutions and to bodies of government that, while taking into account the small differences between each author's division and regulation of political power, in all cases serve as a system of checks and balances against each other, their active engagement with the affairs of state ensuring that the stratum they correspond to is well represented, while preventing others from acquiring boundless power. In this regard, the theories of both classical and early modern republicanism expose a significant weakness in comparison to that of the our era, as the particular roles of the different modes of government are often glanced over and vaguely defined, resulting in a lack of clarity when it comes to division of authority. 
While each of the four aforementioned theorists has a number of unique and original ideas about the particulars, these are mostly relegated to non-essential issues: preferring one mode of government over another, while illuminating in terms of the theorists general perception of politics, is of little consequence when a mixed government is claimed by all to be superior. Likewise, the slight variations in formulating particular laws, managing policy prescriptions and organizing institutional arrangements can be viewed as minor disagreements that merely point to a general broad consensus on all crucial issues, with seemingly no major issue being the cause of separation between either different theories within the same era, or the two eras themselves, returning us to the original question of whether the strong apparent similarity between them may hide a foundational distinction of approach.

Therefore, we must turn to the subtle question of ideal constitutions, the kind that was deeply explored in Plato's Republic. While the matter may seem insignificant, it poignantly reveals the vastest sphere of division between the theories of classical and early modern republican thinkers. Without going into it in nearly as much detail as his teacher, Aristotle still defined a natural aristocracy as the ideal mode of government, with all the other modes, including other aristocracies, being its deviations (Reeve 1998, lxxii); Cicero, having promised to offer his view of the ideal constitution (Cicero 1829, 80), did so in a part of his discourse which was lost to history (Featherstonhaugh 1829), though, judging from his observations about the existing modes of government, we likely wouldn't be remiss in assuming that he saw it as a kind of perfectly ordered monarchy.

Quite strikingly, neither Machiavelli, nor Guicciardini offer any conceptions about the ideal constitution, and the best description of what was probably their shared reasoning on the issue can be found in one of former's most illuminating quotes: "Since my intent is to write something useful to whoever understands it, it has appeared to me more fitting to go directly to the effectual truth of the thing than to the imagination of it. And many have imagined republics and principalities that have never been seen or known to exist in truth; for it is so far from how one lives to how one should live that he who lets go of what is done for what should be done learns his ruin rather than his preservation" (Machiavelli 1998, 61).

The implications of this approach point to a different perception of the very origin of society and state; thus, they also imply a seemingly subtle, but nonetheless crucial distinction in understanding its foundations. While the classical thinkers viewed political community as a naturally emergent phenomenon (Aristotle 1998, 5), the early modern theorists preferred to avoid the issue altogether, seeing no relevance in it for lack of a possible concrete application. However, in a quote strikingly similar to what would later become the basis of the social contract theory, Machiavelli offers his understanding of the formation of the state, observing that people were few and far between, living like beasts in a sparsely populated world; pressed for resources and defense as their numbers grew, they were essentially forced to create a political body as a means of insuring survival (Machiavelli 1996, 11). 
Though he offers no elaboration of this thesis, the Florentine Realists' abandonment of the classical concept of the natural human tendency toward statehood may have paved the way for the social contract theory, signifying one the crucial moments of the modern political thought's departure from its ancient roots. On a more general note in regards to the history of the idea of the state's causes, the Florentine Realists' historically inclined apathy toward the issue can be argued to represent the transitional stage between the ancient, organic, and the modern, individualistic conception of society.

Despite the undeniable influence of classical thinkers on early modern republican theorists, firmly embedded within the spirit of the Renaissance as a period of cultural and intellectual transformation, the differences in perceiving the political phenomenon of the state's initial causes as natural in the former case, and historical in the latter, certainly played a significant part in the somewhat different structuring of theories, offering an explanatory perspective on the generally tenuous, subtle distinctions between the two eras.

\section{Conclusion}

In spite of their small differences, most of which can be reduced to cultural and social circumstances, the theories offered by the early developers of the republican tradition achieve a broad consensus on a number of crucial issues, and thus may hold the key to solving the problems inherit in very foundations of the later currents within the tradition. While clearly surpassed in the area of specifically defined roles of the modes of government, classical and early modern republican thought, founded on the concept of mixed government, could offer an additional layer of branching that would enable us to overcome the problem of a lack of political representation stemming from economic inequality.

John McCormick lays the foundation for exploring this concept, arguing that the democratic element is lacking in modern politics, particularly in the United States: he explores a potential solution through a thought experiment, proposing the enactment of the institution of popular tribunes via a constitutional amendment (McCormick 2011, 179). Whether or not such a development ever really occurs, the very recognition that solutions can be found in the past is hopeful in itself.

Specifically, in the context of mixed government being contrasted with separation of powers, the two different tripartite divisions of government offer divergent, but potentially compatible solutions to the problems presented by political reality. And while the deficiencies of the present system of governmental branching could eventually lead to a clamor for its complete replacement with the alternative concept, the shortcomings of mixed government necessitate a union between the two which, much like the systems proposed by the four theorists, would seek to combine the virtues of the two, while transcending their vices.

Changes to existing systems that would improve the political balance between the social strata would, of course, be extremely complex, and would require great knowledge of individual systems in which their application would 
be attempted, but their general characteristics would include introducing elections to certain offices by lot, which tend to negate the political privileges of wealth and recognition, an institution in the spirit of public accusation discussed by Machiavelli, eligible to be leveled at any public official, regardless of his station, and a citizen body, much like Piero Soderini's Great Council, the contestatory role of which would greatly improve the balance in representation and fundamentally increase the legitimacy of the decision-making process.

\section{References}

Aristotle. 1998. Politics. Translated by C. D. C. Reeve. Indianapolis and Cambridge: Hackett Publishing Company.

Cicero, Marcus Tullius. 1829. "On the Commonwealth." In The Republic of Cicero, translated and edited by G. W. Featherstonhaugh, 33-148. New York: G. \& C. Carwill.

Guicciardini, Francesco. 1998. "Discorso di Logrogno/On How to Order Popular Government." In Republican Realism in Renaissance Florence edited by Athanasios Moulakis, 117-149. Lanham, Maryland: Rowman \& Littlefield Publishers, Inc.

Featherstonhaugh, G. W. Introduction to The Republic of Cicero, translated and edited by G. W. Featherstonhaugh, 2-31. New York: G. \& C. Carwill.

Kahn, Victoria. 2010. "Machiavelli's Afterlife and Reputation to the Eighteenth Century." In The Cambridge Companion to Machiavelli, edited by John M. Najemy, 239-256. Cambridge: Cambridge University Press.

Machiavelli, Niccolo. 1996. Discourses on Livy. Translated by Harvey C. Mansfield and Nathan Tarcov. Chicago: The University of Chicago Press.

Machiavelli, Niccolo. 1998. The Prince. Translated by Harvey C. Mansfeld. Chicago: The University of Chicago Press.

Mansfield, Harvey C., and Nathan Tarcov. 1996. Introduction to Discourses on Livy by Niccolo Machiavelli, xvii-xliv. Chicago: The University of Chicago Press.

McCormick, John P. 2001. "Machiavellian Democracy: Controlling Elites with Ferocious Populism." American Political Science Review 95(2): 297-313.

McCormick, John P. 2011. Machiavellian Democracy. Cambridge: Cambridge University Press.

Montesquieu, Charles-Louis. 1989. The Spirit of the Laws. Edited by Anne M. Cohler, Basia Carolyn Miller and Harold Samuel Stone. Cambridge: Cambridge University Press.

Moulakis, Athanasios. 1998. Republican Realism in Renaissance Florence. Lanham, Maryland: Rowman \& Littlefield Publishers, Inc.

Plato. 2005. Republic. Translated by C. D. C. Reeve. Indianapolis and Cambridge: Hackett Publishing Company. 
Pocock, J. G. A. 2010. "Machiavelli and Rome: The Republic as Ideal and as History." In The Cambridge Companion to Machiavelli, edited by John M. Najemy, 144-156. Cambridge: Cambridge University Press.

Reeve, C. D. C. 1998. Introduction to Politics, by Aristotle, xvii-lxxix. Indianapolis and Cambridge: Hackett Publishing Company.

Strauss, Leo. 1957. "Machiavelli's Intention: The Prince." The American Political Science Review 51(1): 13-40. 